\title{
PENGARUH MEDIA KOMIK DALAM MENINGKATKAN KEMAMPUAN MENULIS TEKS NEGOSIASI PADA SISWA KELAS X SMA SANTU PETRUS SIDIKALANG
}

\author{
PRATIWI NOVITA TINAMBUNAN \\ pratiwinovitatinambunan@gmail.com \\ Universitas Katolik Santo Thomas Medan
}

\begin{abstract}
Abstrak Penelitian ini bertujuan untuk mengetahui pengaruh media komik dalam meningkatkan kemampuan menulis teks negosiasi. Metode yang digunakan dalam penelitian ini adalah metode eksperimen, yaitu cara atau media yang mengungkapkan fakta yang jelas dengan desain Static Group Comparison. Teknik pengambilan sampel yang digunakan adalah simple random sampling, sampel penelitian ini sebanyak 60 siswa kelas XMIA1 dan XMIA2. Instrument yang digunakan dalam pengumpulan data adalah test-essay dalam bentuk penugasan, yaitu menulis teks negosiasi.Pengujian hipotesis dilakukan dengan menggunakan uji " $\mathrm{t}$ ". Temuan dalam penelitian ini menunjukkan bahwa kemampuan siswa dalam menulis teks negosiasi sebelum menggunakan media komik termasuk dalam kategori cukup dengan nilai rata-rata 72,4. Sedangkan sesudah menggunakan media komik termasuk dalam kategori baik dengan nilai rata-rata 84 . Selanjutkan pengujian hipotesis menunjukkan $\mathrm{H}_{\text {hitung }}>\mathrm{t}_{\text {tabel }}$ yakni 8,46 $>2,00$ pada taraf signifikan $\alpha=0,05$ atau 5\%. Dengan demikian, terbukti bahwa hipotesis alternatif $\left(\mathrm{H}_{\mathrm{a}}\right)$ diterima dan dapat dinyatakan bahwa media komik berpengaruh terhadap kemampuan siswa dalam menulis teks negosiasi oleh siswa kelas X SMA Santu Petrus Sidikalang.
\end{abstract}

\section{Kata Kunci: Menulis Teks Negosiasi, Media Komik.}

Abstract. This study aims to determine the effect of comic media in improving the ability to write negotiating texts. This research was conducted at SMA Santu Petrus Sidikalang. The method used in this research is an experimental method, which is a method or media that reveals clear facts with the Static Group Comparison design. The population of this study were all students of class X SMA Santu Petrus Sidikalang which consisted of 3 classes with a total of 105 people. The sampling technique used was simple random sampling. The sample of this study was 60 students of class XMIA1 and XMIA2. The instrument used in collection the data was essay-test in the form of an assignment, namely writing a negotiation text. Hypothesis testing is done using the "t".The findings in this study indicate that the students' ability in writing negotiating texts before using comic strips was in the sufficient category with an average score of 72,4. Meanwhile, after using comic media, it is in the good category with an average score of 84 . Continuing to test the hypothesis, it shows that the $\mathrm{H}_{\text {hitung }}>\mathrm{t}$ table is $8,46>2.00$ at the significant level $\alpha=0.05$ or $5 \%$. Thus, it is proven that the alternative hypothesis (Ha) is accepted and it can be stated that the comic media influences the students' ability in writing negotiating texts by the tenth grade students of SMA Santu Petrus Sidikalang.

Key words: Writing Negotiation Text, Comic Media.

\section{PENDAHULUAN}

Keterampilan menulis dianggap sebagai keterampilan berbahasa yang paling sulit untuk dikuasai bahkan oleh penutur ahli bahasa yang bersangkutan sekalipun. Keterampilan berbahasa mencakup empat aspek, yaitu keterampilan mendengarkan, keterampilan berbicara, keterampilan membaca dan keterampilan menulis. Sebagai bagian dari keterampilan berbahasa, menulis berkaitan erat dengan aktivitas berpikir dan pengungkapan imajinasi perasaan seseorang dalam bentuk tulisan yang indah. 


\section{PRATIWI NOVITA TINAMBUNAN \\ PENGARUH MEDIA KOMIK DALAM MENINGKATKAN KEMAMPUAN MENULIS TEKS NEGOSIASI PADA SISWA KELAS X SMA SANTU PETRUS SIDIKALANG}

Menulis merupakan cara berbicara tidak langsung untuk mengungkapkan gagasan, perasaan, pikiran dan kemauan kepada orang lain secara tertulis. Melalui keterampilan menulis diharapkan siswa dapat memaparkan dan mengungkapkan gagasan atau pikiran serta menjelaskan informasi dan menerangkan sesuatu secara mandiri. Keterampilan menulis seseorang bukan merupakan bakat, tetapi keterampilan yang dapat dikembangkan melalui latihan yang berkesinambungan.

Negosiasi dilakukan karena pihakpihak yang berkepentingan perlu membuat kesepakatan mengenai persoalan yang menuntut penyelesaian bersama. Tujuan negosiasi adalah untuk mengurangi perbedaan posisi setiap pihak. Selain itu, bentuk atau struktur interaksi yang direncanakan juga perlu disepakati, misalnya dialog langsung atau dialog tidak langsung. Struktur teks negosiasi di dalam dialog negosiasi antara pihak satu dan pihak dua terdiri dari tiga bagian yaitu kalimat pembukaan, kalimat isi dan kalimat penutup.

Hambatan yang dialami dalam pembelajaran menulis teks negosiasi yaitu siswa kurang tertarik dalam kegiatan menulis teks negosiasi karena media pembelajaran kurang memotivasi siswa. Guru masih menerapkan pembelajaran menggunakan metode ceramah. Proses pembelajaran ini bersifat monoton sehingga siswa tidak berperan aktif saat proses belajar berlangsung. Kemampuan siswa dalam menulis teks negosiasi harus ditingkatkan karena dengan adanya kemampuan siswa menulis teks negosiasi siswa diajak untuk lebih bijak dalam interaksi sosial.

Penggunaan media pembelajaran akan membantu siswa untuk mencapai keberhasilan dan pelaksanaan pembelajaran akan lebih menarik perhatian siswa saat melakukan pembelajaran. Salah satu media hiburan yang dapat digunakan untuk membantu pembelajaran di kelas adalah komik. Berdasarkan uraian tersebut, peneliti tertarik untuk melakukan penelitian dengan judul "Pengaruh Media Komik dalam Meningkatkan Kemampuan Menulis Teks Negosiasi pada Siswa Kelas X SMA Santu Petrus Sidikalang.

Rumusan masalah dalam penelitian ini adalah sebagai berikut: 1)Bagaimanakah kemampuan menulis teks negosiasi siswa kelas X SMA Santu Petrus Sidikalang tanpa menggunakan media komik ?. 2)Bagaimanakah kemampuan menulis teks negosiasi siswa kelas X SMA Santu Petrus Sidikalang dengan menggunakan media komik ?. 3)Adakah pengaruh media komik dalam meningkatkan kemampuan menulis teks negosiasi pada siswa kelas X SMA Santu Petrus Sidikalang?

Adapun tujuan penelitian adalah sebagai berikut: 1)Untuk menggambarkan kemampuan menulis teks negosiasi siswa kelas X SMA Santu Petrus Sidikalang tanpa menggunakan media komik. 2)Untuk menggambarkan kemampuan menulis teks negosiasi siswa kelas X SMA Santu Petrus Sidikalang dengan menggunakan media komik. 3)Untuk menggambarkan pengaruh media komik dalam meningkatkan kemampuan menulis teks negosiasi pada siswa kelas X SMA Santu Petrus Sidikalang.

Teks negosiasi tergolong ke dalam bentuk teks diskusi (discussion). Kegiatan itu berisi adu tawar yang kemudian berujung pada kesepakatan atau ketidaksepakatan. Istilah lain dari adu tawar keinginan itu, diistilahkan dengan negosiasi. Adu tawar atau negosiasi ternyata sering terjadi dalam berbagai kesempatan. Bahkan, dapat dikatakan bahwa ketika berhubungan dengan orang lain, kita tidak bisa lepas dengan proses negosiasi, tetapi dalam bentuk dan tingkat kepentingan yang berbeda-beda.

Penggunaan media komik sebagai alternatif guru untuk meningkatkan keaktifan siswa dalam menulis teks negosiasi. Penggunaan media komik dapat meningkatkan keterampilan menulis teks negosiasi siswa karena dengan melalui media komik siswa akan mendapat gambaran yang konkret tentang seseorang yang sedang melakukan proses negosiasi, sehingga dalam menulis teks negosiasi siswa mampu dengan mudah menuangkan gagasan yang ada dalam pikirannya. Hipotesis penelitian ini adalah pengaruh media komik dalam meningkatkan kemampuan menulis teks negosiasi pada siswa kelas X SMA Santu Petrus Sidikalang

\section{METODE PENELITIAN}

Metode yang digunakan adalah metode kuantitatif yang diarahkan dalam bentuk mencari data-data kuantitatif melalui hasil uji coba eksperimen. Adapun tujuan penelitian ini untuk mengetahui pengaruh media komik dalam meningkatkan kemampuan menulis teks negosiasi pada siswa kelas X SMA Santu Petrus Sidikalang. Populasi dalam penelitian ini adalah seluruh siswa kelas X-MIA SMA Santu Petrus Sidikalang yang selanjutnya dilakukan pemilihan secara acak sehingga diperoleh kelas eksperimen X-MIA 1 sebanyak 30 orang dan kelas kontrol X-MIA 2 sebanyak 30 orang. Teknik pengumpulan data merupakan cara yang dilakukan peneliti untuk mengungkap atau menjaring 


\section{PRATIWI NOVITA TINAMBUNAN \\ PENGARUH MEDIA KOMIK DALAM MENINGKATKAN KEMAMPUAN MENULIS TEKS NEGOSIASI PADA SISWA KELAS X SMA SANTU PETRUS SIDIKALANG}

informasi kuantitatif dari responden sesuai lingkup penelitian. Teknik pengumpulan data yang digunakan dalam penelitian ini adalah tes essay. Instrumen yang digunakan dalam penelitian ini berupa post-test. Aspek yang dinilai dalam teks negosiasi antara lain: (1) isi, (2) organisasi, (3) tata bahasa dan diksi, (4) gaya, (5) kerapian tulisan, (6) uji normalitas, (7) uji hipotesis dengan menggunakan uji " $t$ ". Setelah $t_{\text {hitung }}$ diketahui kemudian dikonsultasikan dengan harga $t_{\text {tabel }}$ dengan taraf kesalahan $\alpha=5 \%$ dan harga dk dengan harga 2,00. Maka hipotesis nihil $\left(\mathrm{H}_{\mathrm{o}}\right)$ ditolak dan hipotesis alternatif $\left(\mathrm{H}_{\mathrm{a}}\right)$ diterima.

\section{HASIL DAN PEMBAHASAN \\ 1. Hasil Penelitian}

Berdasarkan hasil penelitian, maka diperoleh temuan penelitian sebagai berikut: (1)Kemampuan siswa dalam menulis teks negosiasi tanpa menggunakan media komik menunjukkan rata-rata 72,4 termasuk dalam kategori cukup. (2)Kemampuan siswa dalam menulis teks negosiasi dengan menggunakan media komik menunjukkan rata-rata 84 termasuk dalam kategori baik. (3)Berdasarkan perhitungan dengan uji " $\mathrm{t}$ " diperoleh nilai to $=8,46$ kemudian dikonsultasikan dengan tabel $\mathrm{t}$ pada taraf signifikan $0,5 \%$ dengan dk 58 adalah 2,00 nihil (Ho) ditolak dan hipotesis alternatif (Ha) diterima.

Setelah melakukan penelitian, tanpa menggunakan media komik yang dilakukan pada siswa kelas X SMA Santu Petrus Sidikalang dalam menulis teks negosiasi masih dalam kategori cukup. Dalam penilaiannya terbagi dalam lima kategori, yaitu sangat baik sebanyak 0 siswa atau $0 \%$, kategori baik sebanyak 9 siswa atau 30\%, kategori cukup sebanyak 21 siswa atau 70\%, kategori kurang sebanyak 0 siswa atau $0 \%$, dan kategori tidak baik sebanyak 0 siswa atau $0 \%$.

Setelah melakukan penelitian dengan menggunakan media komik yang dilakukan pada siswa kelas X SMA Santu Petrus Sidikalang dalam menulis teks negosiasi masih dalam kategori baik. Dalam penilaiannya terbagi dalam lima kategori yaitu sangat baik sebanyak 15 siswa atau $50 \%$, kategori baik sebanyak 13 siswa atau $43.33 \%$, kategori cukup sebanyak 2 siswa atau 6.6\%, kategori kurang sebanyak 0 siswa atau $0 \%$, dan kategori tidak baik sebanyak 0 siswa atau $0 \%$.

Menulis adalah salah satu kegiatan untuk menuangkan pikiran, gagasan dan perasaan seseorang yang diungkapkan dalam bahasa tulis dan menulis juga merupakan kegiatan yang dapat menambah kreatif siswa. Dalam media pembelajaran yang dilakukan oleh peneliti memiliki kelebihan yang signifikan dimana dengan menggunakan media komik siswa lebih aktif dalam proses pembelajaran serta siswa mampu menuangkan ide-ide yang kreatif pada saat pembelajaran berlangsung.

Penggunaan media pembelajaran dengan media komik membuat kemampuan menulis teks negosiasi baik dan nilai yang diperoleh siswa baik. Media komik merupakan suatu medium yang sangat efektif untuk membantu proses pembelajaran, baik untuk pembelajaran massal, individual, maupun berkelompok. Melalui media pembelajaran ini informasi dapat disajikan dengan tepat, siswa dapat mengulang pembelajaran, siswa akan semakin lebih aktif, terfokus, termotivasi dan bekerja sama.

Dari penelitian yang sudah dilaksanakan, maka dapat disimpulkan bahwa hasil belajar siswa dengan menggunakan media pembelajaran yaitu komik berpengaruh signifikan terhadap pembelajaran menulis teks negosiasi. Media pembelajaran yaitu komik dikatakan berpengaruh signifikan karena media ini menuntut siswa fokus pada negosiasi yang dijelaskan guru lewat media komik. Selanjutnya, mereka juga dapat mengamati kembali komik yang diberikan sehingga siswa akan lebih aktif, peka terhadap materi yang disampaikan dan mampu menuangkan dalam tulisan serta durasi ingatan otak akan tersimpan lebih lama.

Hasil belajar siswa dengan menggunakan pembelajaran media komik lebih baik dibandingkan dengan tanpa menggunakan media pembelajaran khususnya dalam menulis teks negosiasi. Oleh karena itu, dalam proses belajar dan mengajar diperlukan sebuah media yang baik, menarik sehingga dapat menjadi masukan bagi guru untuk lebih kreatif dalam memilih media pembelajaran agar proses pembelajaran berjalan dengan lancar dan tujuan pembelajaran juga tercapai dengan maksimal.

\section{SIMPULAN}

Berdasarkan hasil penelitian yang telah diuraikan di atas, maka dapat disimpulkan sebagai berikut, (1)Nilai ratarata kemampuan menulis teks negosiasi kelas X SMA Santu Petrus Sidikalang tanpa menggunakan media pembelajaran (media komik) adalah 72,4. (2)Nilai rata-rata kemampuan menulis teks negosiasi kelas $\mathrm{X}$ SMA Santu Petrus Sidikalang dengan menggunakan media pembelajaran (media komik) adalah 84. (3)Kemampuan menulis teks negosiasi dengan media komik lebih 


\section{PENGARUH MEDIA KOMIK DALAM MENINGKATKAN KEMAMPUAN \\ MENULIS TEKS NEGOSIASI PADA SISWA KELAS X SMA SANTU \\ PETRUS SIDIKALANG}

baik daripada menulis teks negosiasi tanpa menggunakan media komik. (4)Adanya pengaruh media komik dalam meningkatkan kemampuan menulis teks negosiasi pada siswa kelas X SMA Santu Petrus Sidikalang.

\section{DAFTAR PUSTAKA}

Arikunto. Suharsimi. 2017. Prosedur Penelitian Suatu Pendekatan Praktik. Jakarta: Rhineka Cipta

Arsyad.Azhar. 2013. Media Pembelajaran edisi revisi xvi. Jakarta: Rajawali Pers

Daryanto. 2013. Media Pembelajaran Peranannya Sangat Penting Dalam Mencapai Tujuan Pembelajaran. Yogyakarta: Gava Media

Kosasih. E. 2014. Jenis-jenis teks (analisis, fungsi, struktur, dan kaidah serta langkah penulisannya). Bandung: Yramada Widya

Sugiyono.2016. Metode Penelitian Kuantitatif Kualitatif dan $R \& D$. Bandung. Alfabeta

Sujana dan Rivai. 2001. Media Pengajaran. Bandung: Sinar Baru Aglesindo

Trimo. 1997. Media Pendidikan. Jakarta: Depdikbud 